\title{
Effect of Rice Straw Mulchingon Water Use Efficiency, Growth, Yield and Quality of King Ruby Grape under Surface Irrigation
}

\author{
"A.M. Abo-Ogiala and ${ }^{* *}$ Naglaa E. Khalafallah \\ *Horticulture Department, Faculty of Agriculture, Tanta University and ${ }^{* *}$ Soil and \\ Water Department, Faculty of Agriculture, Tanta University, Tanta, Egypt.
}

\begin{abstract}
$\mathbf{N}^{\mathrm{s}}$ EW agriculture practices are required for developing water use efficiency. Mulching as a target for that goalhas not been adequately quantified. The aim of this work was to clarify the role of rice straw mulchingin reserving water under surface irrigation and quantify its application benefits on yield and quality of king ruby grape vineyard grown in Delta Nile of Egypt during 2017 and 2018 seasons. The experimental layout included six treatments T1, T3 and T5 for three irrigation regimes which introduced control or zero, 25\% and 50\% of restriction irrigation water. T2, T4 and T6 introduced the mulching application within the previous irrigation regimes. The irrigation regime started at veraison phase (pre maturity stage) from May 2017 till end of July (time of harvest) and straw mulches were applied at rate 5 $\mathrm{kg} / \mathrm{m}^{2}$, and it was renewed in 2018 season. Soilbulk density (BD), infiltration rate (IR) and NPK uptake were looked up. Growth and qualities attributes were figured out as a reflection affect by treatments under investigations. Results highlighted the role of mulching in keeping soil moisture under severe drought stress, $50 \%$ of restriction irrigation water (T6) similar to unstressed, control (T1) subsequently the most measured parameter of soil, growth and quality were similar in both treatments. These findings suggest the application of $\mathrm{T} 6(50 \%$ of restriction irrigation water) treatment as a target recommendation for saving $50 \%$ of irrigation water without yield reduction and with good qualities.
\end{abstract}

Keywords: King ruby cultivar, Ricestraw, Mulching, Water use efficiency, Surface irrigation, Yield, Quality.

\section{Introduction}

Grape (Vitisvinifera L) is one of the most important fruits worldwide for not only fresh consumption but also for raisins and juice making. In Egypt, grape is the second major fruit crop after citrus. Ruby Seedless cultivar takes special attention as table grapes in local and export markets. Good qualities that include a combination of medium size cluster with uniform colored berries beside pleasant flavor and texture are always of interest. Increasing the amount of water led to negative impacts on grapes qualities (Valdés et al., 2009 and Basileet al. 2011). Many studies worldwide have been showed thatgrapevine water deficit reflected reduction ofcanopydevelopment, yield andchanging composition of fruits (Bravdo et al., 1985, Matthews \& Anderson, 1989, Kennedy et al., 2002, Robyet al., 2004, Castellarinet al., 2007, Bindonet al., 2008 and Pellegrino et al. 2014).
However, deficit irrigation throughout the growing season led to enhanced colors and quality of red grapes (Williams and Matthews, 1990, Santos et al., 2007). Furthermore, Deluc et al. (2009) found that water deficit promote sugar accumulation due to the inhibition of lateral shoot growth which lead to reallocation of carbohydrates to the fruits, or may due to the direct effect of ABA-mediated uptake of hexoses.Ginestar et al. (1998) found that reduction in berry sugar accumulation was related to the reduction in photosynthesis rate. Imposing water deficit early in the start season is resulting inhibition of vegetative growth and berry size (McCarthy et al., 2002). However, the imposing water deficit after veraison may enhance anthocyanin accumulation (Dry et al., 2001). Numerous benefits of mulching were reported by several studies including the increase of nitrogen and other nutrients in soils due to the inhibition of leaching and evaporation (Agnew et al., 2002

Corresponding author:Atef Mostafa Abo-Ogiala, e-mail: atef_aboogiala@yahoo.com

DOI: 10.21608/ejoh.2018.6795.1092

(C)2019 National Information and Documentation Centre (NIDOC) 
\& 2005, Ross, 2010 and Nguyen et al., 2013). Moreover,the inhibition in weed germination subsequently reduction in herbicide applications as related to mulching were reported (Elmore et al., 1998, Frederikson et al., 2011 and Steinmaus et al., 2008). In addition, mulching found to be useful for soil characteristics (Agnew et al., 2002, Göblyöset al., 2011 and Némethy, 2004). On the other hand, mulching increase water use efficiency were reduced the water evaporation from soilsurfaces (Gregory, 2004 and Davies et al., 2011). Agnew et al. (2002) found that soil moisture increased $5 \%$ in the upper part of the soil profile $(0-30 \mathrm{~cm})$ and $3.4 \%$ in soil profile between (30-60) under mulching compared to till one. Zhang et al. (2014) reported that rice straw mulching increase water use efficiency and the yield of grapevines.Moreover, straw mulching increased water use efficiency by saving 30\% of irrigation water (Chaudhryet al., 2004, Zhang et al., 2005 and Laila \& Ali 2011). In addition, Chan et al., (2010) found that composted mulch were lead to $30 \%$ increase of saving irrigation water used in vineyard.Two aims of this study were followed, the first is to reserve the amount of water used in irrigation and the second is to improve the production and the quality of King Ruby grape cultivar.

\section{Material and Methods}

Research site

Field experiments were conducted during 2017 and 2018 seasons in a 4-years-old vineyard of Vitisvinifera 'king ruby'on own roots with planting space of $3 \mathrm{~m}$ between rows and $2 \mathrm{~m}$ within rows resulting density of 700 vines/ feddan in private farm located in Abou El-Ghar village, Kafr El-Zayat, Gharbiya governorate, Egypt. Before the start of the experiment soil characteristics were figure out as shown in Table 1.

TABLE 1. Orchard Soil characteristics of vineyard King ruby cultivar at the start of the experiment.

\begin{tabular}{|c|c|c|c|c|c|c|c|c|c|}
\hline \multirow[t]{2}{*}{$\begin{array}{l}\text { Soildepth } \\
\text { cm }\end{array}$} & \multicolumn{3}{|c|}{ Particle size distribution \% } & \multirow[t]{2}{*}{ pH } & \multirow[t]{2}{*}{$\begin{array}{c}\text { EC } \\
\text { dS m m }\end{array}$} & \multirow[t]{2}{*}{$\begin{array}{l}\text { O.M } \\
\text { g Kg- }\end{array}$} & \multicolumn{3}{|c|}{$\begin{array}{c}\text { Available NPK } \\
\mathrm{mg} \mathrm{Kg}^{-1}\end{array}$} \\
\hline & Clay & Silt & Sand & & & & $\mathbf{N}$ & $\mathbf{P}$ & $\mathbf{K}$ \\
\hline $0-30$ & 46.21 & 23.27 & 31.42 & 8.24 & 2.21 & 11.56 & 49.12 & 4.14 & 197.56 \\
\hline $60-90$ & 44.78 & 22.54 & 31.24 & 8.26 & 2.23 & 11.21 & 45.75 & 3.89 & 195.35 \\
\hline
\end{tabular}

Vines were trained according to Spanish Barron trellis and arms were positioned upwards in four directions. Before the start season, vines were pruned to 12 cansdistributed on the four arms. When cluster reached around $10 \mathrm{~cm}$ length, the crop load was normalized to 25 bunches per plant. Vines under investigation were received normal agriculture practices inclusive fertilization, pests and diseases control.

\section{The experiment layout}

The experiment started at veraison phase (pre mature stage) from May till end of July (time of harvest). The experiment consists of six treatments each had three replicates inclusive three vines for each which introduced T1, T3 and $\mathrm{T} 5$ for three irrigation regimes, control or zero, $25 \%$ and $50 \%$ of restriction irrigation water i.e. $(70.09 \%, 60.37 \%$ and $55.54 \%$ soil moisture as a percent of field capacity), respectively. T2, T4 and T6 introduced the mulching application within the previous irrigation regimes. The trail arranged in a complete randomize block design represents three irrigation regimes (zero, moderate and severe drought stress, respectively) including rice straw mulching treatments within them as follow and shown in Fig. 1. The straw mulches were applied in the start of May 2017 at rate $5 \mathrm{~kg} / \mathrm{m}^{2}$, and it was renewed in 2018.

$\mathrm{T} 1$ :irrigation regime with 10 days intervals, $70.09 \%$ soil moisture as a percent of field capacity $\mathrm{T} 2$ :same irrigation regime of $\mathrm{T} 1$ with rice straw mulching

T3: $25 \%$ of restriction irrigation water, 15 days intervals, $60.37 \%$ soil moisture of field capacity

T4: same irrigation regime of $\mathrm{T} 3$ with rice straw mulching

T5: $50 \%$ of restriction irrigation water, 20 days intervals, $55.54 \%$ soil moisture of field capacity T6: same irrigation regime of $\mathrm{T} 4$ with rice straw mulching 


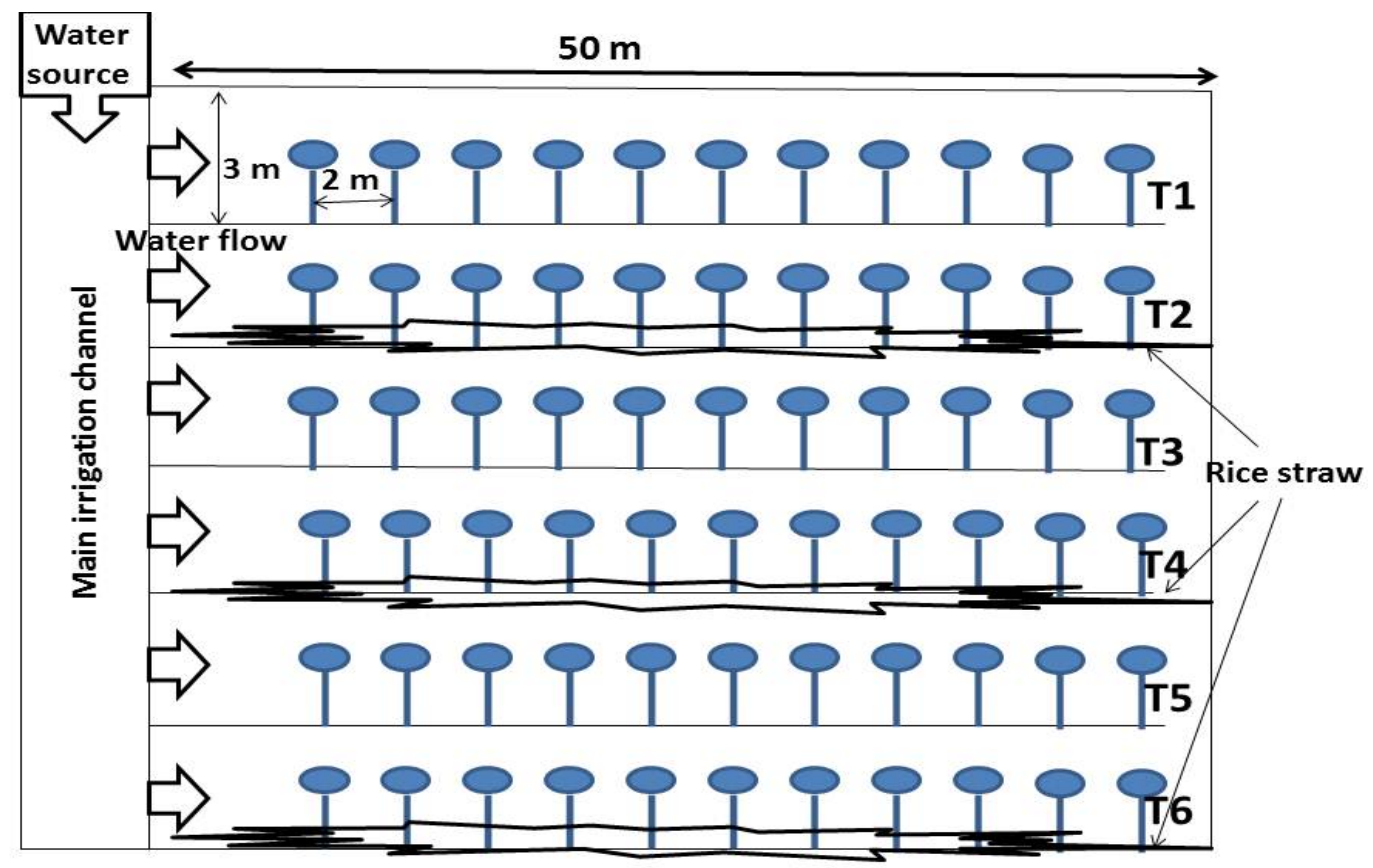

Fig. 1. the layout of the field experimental design, T1 and T2 refers to zero drought stress without and with rice straw over the ground, respectively. $\mathrm{T} 3$ and $\mathrm{T} 4$ refer to moderate drought stress. $\mathrm{T} 5$ and $\mathrm{T} 6$ refer to the severe drought stress.

\section{Soil attributes}

The soil samples from the surface layer $(0$ to $30 \mathrm{~cm}$ ) and a medium (30 to $60 \mathrm{~cm}$ ) were collected. Micro-kjeldehl method as described by (page, 1982) was used for nitrogen determination, Cotteineet al., (1982) was followed for Phosphorus and Flame photometer was used for Potassium (K) according Jackson (1967).Bulk density (BD) was measured using the core method (Grossman and Reinsch, 2002) and Infiltration rate(IR)was determined by using double ring with applying 15 $\mathrm{cm}$ depth of water. Then, the infiltration time were recorded for each plot. After that, the average of thesevalues was calculated for each treatment. Basic infiltration rate (IR) was calculated using the equation ofKostiakov(1932) as follows:

$$
\mathrm{IR}=\mathrm{KT}^{\mathrm{n}}
$$

Where, IR is the cumulative infiltration after time $\mathrm{T}, \mathrm{T}=$ Time after infiltration starts, $\mathrm{K}$ and $\mathrm{n}$ are constants that depend on the soil and initial conditions (evaluated from measured infiltration data. $\mathrm{K}$ and $\mathrm{n}$ values range between zero to 1 .

Available water (AW)was calculated according Klute (1986) by subtracting permanent wilting point $(-1500 \mathrm{kpa})$ from field capacity $(-33 \mathrm{kpa})$ as follow:

$$
\mathrm{AW}=\mathrm{FC}-\mathrm{WP}
$$

Where, FC is the water content at field capacity, WP is the water content at permanent wilting point.

\section{Some vegetative growth measurements}

These measurements were taken one month later of the start of the experiment, shoot length measured by $\mathrm{cm}$, single leaf area was measured using the fifth leaf from the shoot tip using the device meter model CI 203, USA, then multiplied by the average number of leaves/shoot and then multiplied by number of shoots/vine. Bud burst $\%$ was calculated at the following season of the experiment according to the following equation:

Bud Burst $\%=\frac{\text { (Number of brusted buds/vine) }}{(\text { Total number of buds left/vine (40)) }} \times 100$

\section{Some yield indicators}

Yield calculated by average cluster weight multiplied by number of cluster/vine and Bud fertility \% was calculated according to Omran (2000) as the following equation:

Bud fertility $\%=\frac{\text { (Number of clusters } / \text { vine })}{(\text { Total number of buds left } / \text { vine (40)) }} \times 100$ 
Some Fruit physical and chemical measurements

Average cluster length and width, berry length and width, and volume juice of 100 berries were determined.Harvest was done at the level of TSS of $16-17 \%$ according to Hamza (2013). Total sugars, anthocyanins and acidity in juice were followed according (A.O.A.C., 2000). Hand refractometer was used to determine total soluble solids (TSS) as Brix.

\section{Total chlorophyll and carbohydrate}

Leaf total chlorophyll (mg $\mathrm{g} \mathrm{FW}^{-1}$ ) was determined according to Von-Wettstein (1957). Total carbohydrates in the canes (\%) were determined according to Hedge and Hofreiter (1962).

\section{Petiole content}

Same method for NPK determinations were used as mentioned in soil analysis part. Calcium was measured using atomic absorption spectrophotometer Perkin Elmer-3300 according chapman and Pratt (1961).Magnesium (Mg) was determined according to Wilde et al. (1985).

\section{Statistical analysis}

Data were analyzed by Statistical Graphics Corporation, STATGRAPHICS Plus (St. Louis, MO, USA) for one way analysis of variance and employing Duncan's multiple range tests (Duncan, 1955) at the 0.05 confidence level and for principle component analysis (PCA).

\section{Results and Discussion}

\section{Soilattributes}

The mean results of soil analysis revealed that soil moisture as a percent of field capacity was significantly raised from $70.09 \%$ in $\mathrm{T} 1$ to 78.28 $\%$ in T2, also from $60.37 \%$ in T3 to $69.97 \%$ in T4 and from $55.54 \%$ in T5 to $63.98 \%$ in T6.

The effects of the experimental treatments on soil proprieties were illustrated in Table 2. The infiltration rate (IR) represents the ability of soil in water- solute transportation (Reynolds et al., 2000 and Carter et al., 2004). Results in Table 2 showed that highest IRwas found in T2 treatment (rice straw cover without any restriction of irrigation water, or mulching control) flowed by $\mathrm{T} 4$ (rice straw cover under $25 \%$ of restriction irrigation water), then flowed by T6 (rice straw cover under $50 \%$ of restriction irrigation water). The IRin T6 was similar to T1 (control treatment or the normal irrigation regime without any restriction of irrigation water in the absent of rice straw cover). The lowest results of IRwere found in T5 and T3 (under $50 \%$ and $25 \%$ of restriction irrigation water in the absent of rice straw cover, respectively).

T1 (control), T2 (mulch control), T3 (25\% of restriction irrigation water), T4 (25\% of restriction irrigation water with mulching), T5 (50\% of restriction irrigation water), T6 (50\% of restriction

TABLE 2. The effect of rice straw mulching and the restriction of irrigation water on soil infiltration rate (IR), soilbulk density (BD), soil available water (AW) and soil content of NPK in the trail field of king ruby grape during 2017 and 2018 seasons.

\begin{tabular}{ccccccccccccc}
\hline & & & & & & & & & & & & \\
\hline
\end{tabular}

$\mathrm{T} 1$ (control), T2 (mulch control), T3 (25\% of restriction irrigation water), T4 (25\% of restriction irrigation water with mulching), $\mathrm{T} 5$ (50\% of restriction irrigation water), T6 (50\% of restriction irrigation water with mulching), Nitrogen (N), Phosphorus (P), Potassium (K), Means followed by the same letter are not statistically different by Duncan at 0.05 levels.

Egypt. J. Hort. Vol. 46, No.1 (2019) 
irrigation water with mulching), Nitrogen $(\mathrm{N})$, Phosphorus (P), Potassium (K), Means followed by the same letter are not statistically different by Duncan at 0.05 levels.

Bulk density (BD) of the soil considered an indicator for improving soil porosity, subsequently aeration according to (Jones et al., 2003). The results of BD in Table 2 revealed that mulching were reduced $\mathrm{BD}$ but this reduction were gradually lost at both of restriction irrigation water. Available water (AW) measure the ability of the soil in holding water. The results of AW in Table 2 were found similar to the results of the infiltration rate (IR) as well. The results of soil content of NPK were similar to the results of the infiltration rate (IR) too as shown in Table 2. These findings are closeconformity with the previous results of (Agnew et al., 2002, Göblyöset al., 2011, Némethy 2004 and Zhang et al., 2014) who reported that mulching are leading to increase of soil moisture retention (available water) enabling a reduction in irrigation, increase of nutrient release subsequently a reduction in fertilizer application, increase of infiltration rate and decrease of bulk density.

\section{Some vegetative growth measurements}

Results in Table 3 showed that mulching in restriction irrigation water (T6) kept soil moister in optimal order which keptshoot length, leaf surface and bud burst equal to that measured under normal irrigation regime (T1, control). However, the same parameters showed significantly higher results in $\mathrm{T} 2$ and $\mathrm{T} 4$ treatments, Table 3On the other hand, absence of mulching in drought stressed vines as in T3 and T5 gave the lowest value Table 3 . These results are in accordance with those obtained by (Agnew et al., 2002 \& 2005, Ross 2010 and Nguyen et al., 2013) who found that mulches improved vines shoot length and leaf surface area inbud burst under drought conditions. Other supporting findings reported by McCarthy et al. (2002) showed that early imposing water deficit resulting inhibition of vegetative growth. More conformity results by Ginestar et al. (1998) who stated that excess water content inhibit photosynthesis subsequently reduce total chlorophyll content. Too much soil water content may contribute to excess vine growth (Hamman \& Dami 2000 and Smart, 1985) but excess vegetative growth generates self-shading leading to a lack of vine balance (Wheeler et al., 2008).

\section{Yield indicators}

Results of yield revealed that $\mathrm{T} 6$ treatment had similar results to $\mathrm{T} 1$ treatment(control) and $\mathrm{T} 3$ treatment without significant differences between them, Table 4.T5 treatment showed the lowest yield followed by $\mathrm{T} 2$ and $\mathrm{T} 4$, respectively, Table 4. Results of bud fertility showed no significant differences betweenT6 and T1 treatments Table4. The lowest bud fertility recorded in T5 then T3, $\mathrm{T} 4$ and T2, respectively, Table 4 . These results are in line with findings from (Valdés et al., 2009 and Basile et al., 2011) who found that excess of water content did not improve grapes yield and berries qualities. Other results are in accordance obtained Chan et al. (2010) found that composted mulch under restriction irrigation regime in vineyard lead to the increase of yield and quality.

Some fruit physical and chemical measurements

It is clear that results of T6 treatment showed no significant differences compared to results of T1 treatment (control) and T3 concerning cluster

TABLE 3. The effect of rice straw mulching and the restriction of irrigation water on shoot length, leaf surface area and bud burst in the trail field of king ruby grape during 2017 and 2018 seasons.

\begin{tabular}{cccccccc}
\hline Parameters & Year & T1 & T2 & T3 & T4 & T5 & T6 \\
\hline Shoot length, cm & 2017 & $112.50 \mathrm{c}$ & $119.11 \mathrm{e}$ & $110.24 \mathrm{~b}$ & $116.21 \mathrm{~d}$ & $107.36 \mathrm{a}$ & $112.24 \mathrm{c}$ \\
\cline { 1 - 5 } & 2018 & $113.45 \mathrm{c}$ & $119.25 \mathrm{e}$ & $111.23 \mathrm{~b}$ & $116.35 \mathrm{~d}$ & $108.52 \mathrm{a}$ & $113.55 \mathrm{c}$ \\
Leaf surface area & 2017 & $99.43 \mathrm{c}$ & $105.32 \mathrm{e}$ & $97.65 \mathrm{~b}$ & $102.35 \mathrm{~d}$ & $95.56 \mathrm{a}$ & $99.32 \mathrm{c}$ \\
cm $^{-2}$ & 2018 & $99.42 \mathrm{c}$ & $105.53 \mathrm{e}$ & $97.66 \mathrm{~b}$ & $102.55 \mathrm{~d}$ & $95.63 \mathrm{a}$ & $99.34 \mathrm{c}$ \\
Bud Brust \% & 2017 & $80.72 \mathrm{c}$ & $83.86 \mathrm{e}$ & $79.63 \mathrm{~b}$ & $82.91 \mathrm{~d}$ & $78.66 \mathrm{a}$ & $80.66 \mathrm{c}$ \\
& 2018 & $80.75 \mathrm{c}$ & $83.88 \mathrm{e}$ & $79.66 \mathrm{~b}$ & $82.88 \mathrm{~d}$ & $78.63 \mathrm{a}$ & $80.65 \mathrm{c}$ \\
\hline
\end{tabular}

T1 (control), T2 (mulch control), T3 (25\% of restriction irrigation water), T4 (25\% of restriction irrigation water with mulching), T5 ( $50 \%$ of restriction irrigation water), T6 (50\% of restriction irrigation water with mulching), Means followed by the same letter are not statistically different by Duncan at 0.05 levels. 
TABLE 4. The effect of rice straw mulching and the restriction of irrigation water on bud fertility and yield in the trail field of king ruby grape during 2017 and 2018 seasons.

\begin{tabular}{cccccccc}
\hline Parameters & Year & T1 & T2 & T3 & T4 & T5 & \multirow{2}{*}{ T6 } \\
\hline \multirow{2}{*}{ Bud fertility \% } & 2017 & $60.55 \mathrm{c}$ & $63.35 \mathrm{e}$ & $59.66 \mathrm{~b}$ & $62.66 \mathrm{~d}$ & $58.66 \mathrm{a}$ & $60.54 \mathrm{c}$ \\
& 2018 & $60.53 \mathrm{c}$ & $63.32 \mathrm{e}$ & $58.65 \mathrm{~b}$ & $62.63 \mathrm{~d}$ & $58.65 \mathrm{a}$ & $60.56 \mathrm{c}$ \\
\multirow{2}{*}{ Yield Kg vine $^{-1}$} & 2017 & $9.61 \mathrm{~b}$ & $10.62 \mathrm{c}$ & $9.58 \mathrm{~b}$ & $10.58 \mathrm{c}$ & $8.56 \mathrm{a}$ & $9.51 \mathrm{~b}$ \\
& 2018 & $9.60 \mathrm{~b}$ & $10.54 \mathrm{c}$ & $9.59 \mathrm{~b}$ & $10.52 \mathrm{c}$ & $8.54 \mathrm{a}$ & $9.55 \mathrm{~b}$ \\
\hline
\end{tabular}

T1 (control), T2 (mulch control), T3 (25\% of restriction irrigation water), T4 (25\% of restriction irrigation water with mulching), T5 ( $50 \%$ of restriction irrigation water), T6 (50\% of restriction irrigation water with mulching), Means followed by the same letter are not statistically different by Duncan at 0.05 levels.

length and width, berry length and width and the juice volume of 100 berries, Table 5 On the other hand, $\mathrm{T} 5$ treatment showed the lowest value for all qualities parameters under investigations but $\mathrm{T} 2$ and T4 treatments gave similar and highest value. The results come in agreements with (Valdés et al., 2009 and Basile et al., 2011) who found that berries qualities did not improve by excess of soil water content.In the same line Wasko (2010) reported that excessive soil moisture wasdelayed fruit ripening and did not enhance berry size.

Soluble solids were slightly increased in T5 treatment, Table 6 T3 and T6 treatments showed similar content of soluble solids, Table 6. T1, T2 and T4 treatments were revealed lowest value of soluble solids without significant differences between them, Table 6 Lowest acidity was observed in $\mathrm{T} 5$ treatment, while the highest value was found in T1, T2 and T4 treatments Table 6 T3 and T6 treatments were showed similar acidity, Table 6 Total sugars outlined opposite results to that found in acidity, where T5 treatment showed slightly the highest total sugar while T1, T2 and T4 treatments showed the lowest value of it. In addition, T3 and T6 treatments were showed similar total sugars, Table 6 . The results of anthocyanin were similar to that outlined in total sugars, Table 6 These results come in agreements with (Williams \& Matthews, 1990 and Santos et al., 2007) who stated that restricted irrigation improved colors and quality of red grapes. Furthermore, Deluc et al. (2009) stated that water deficit enhanced accumulation of sugar in grapes. Moreover, Dry et al. (2001) linked anthocyanin accumulation to water deficit after veraison.

\section{Total chlorophyll and carbohydrate}

Results in Table 7 figured out leaf chlorophyll content and cane carbohydrate content. The

TABLE 5.The effect of rice straw mulching and the restriction of irrigation water on yield, cluster length and width, volume of 100 berries, berry length and width in the trail field of king ruby grape during 2017 and 2018 seasons.

\begin{tabular}{|c|c|c|c|c|c|c|c|c|c|c|}
\hline \multirow{2}{*}{$\begin{array}{l}\text { Parameters } \\
\text { Treatments }\end{array}$} & \multicolumn{2}{|c|}{$\begin{array}{l}\text { Cluster length } \\
\text { (cm) }\end{array}$} & \multicolumn{2}{|c|}{ Cluster width $(\mathrm{cm})$} & \multicolumn{2}{|c|}{$\begin{array}{l}\text { volume of } 100 \text { berries } \\
\qquad\left(\mathrm{cm}^{3}\right)\end{array}$} & \multicolumn{2}{|c|}{$\begin{array}{l}\text { Berry length } \\
(\mathbf{c m})\end{array}$} & \multicolumn{2}{|c|}{$\begin{array}{l}\text { Berry width } \\
\text { (cm) }\end{array}$} \\
\hline & 2017 & 2018 & 2017 & 2018 & 2017 & 2018 & 2017 & 2018 & 2017 & 2018 \\
\hline $\mathrm{T} 1$ & $26.63 b$ & $26.62 b$ & $12.20 \mathrm{~b}$ & $12.21 b$ & $381.37 \mathrm{~b}$ & $381.45 b$ & $1.86 \mathrm{~b}$ & $1.87 \mathrm{~b}$ & $1.65 b$ & $1.66 \mathrm{~b}$ \\
\hline $\mathrm{T} 2$ & $28.59 c$ & $28.61 \mathrm{c}$ & $13.56 \mathrm{c}$ & $13.58 \mathrm{c}$ & $383.54 \mathrm{c}$ & $383.52 \mathrm{c}$ & $1.94 \mathrm{c}$ & $1.93 \mathrm{c}$ & $1.72 \mathrm{c}$ & $1.71 \mathrm{c}$ \\
\hline $\mathrm{T} 3$ & $26.61 b$ & $26.63 b$ & $12.15 b$ & $12.16 \mathrm{~b}$ & $381.38 b$ & $381.34 b$ & $1.86 \mathrm{~b}$ & $1.85 \mathrm{~b}$ & $1.66 b$ & $15.6 \mathrm{~b}$ \\
\hline $\mathrm{T} 4$ & $28.63 \mathrm{c}$ & $28.60 \mathrm{c}$ & $13.57 \mathrm{c}$ & $13.56 \mathrm{c}$ & $383.57 \mathrm{c}$ & $383.53 c$ & $1.92 \mathrm{c}$ & $1.93 \mathrm{c}$ & $1.71 \mathrm{c}$ & $1.72 \mathrm{c}$ \\
\hline $\mathrm{T} 5$ & $22.35 \mathrm{a}$ & $22.71 \mathrm{a}$ & $11.87 \mathrm{a}$ & $11.74 \mathrm{a}$ & $375.65 \mathrm{a}$ & $375.60 \mathrm{a}$ & $1.80 \mathrm{a}$ & $1.81 \mathrm{a}$ & $1.60 \mathrm{a}$ & $1.59 \mathrm{a}$ \\
\hline T6 & $26.58 b$ & $26.59 b$ & $12.21 \mathrm{~b}$ & $12.19 b$ & $381.31 \mathrm{~b}$ & $381.32 \mathrm{~b}$ & $1.86 \mathrm{~b}$ & $1.87 \mathrm{~b}$ & $1.64 b$ & $1.64 b$ \\
\hline
\end{tabular}

T1 (control), T2 (mulch control), T3 (25\% of restriction irrigation water), T4 (25\% of restriction irrigation water with mulching), T5 $(50 \%$ of restriction irrigation water), T6 (50\% of restriction irrigation water with mulching), Means followed by the same letter are not statistically different by Duncan at 0.05 levels.

Egypt. J. Hort. Vol. 46, No.1 (2019) 
TABLE 6. The effect of rice straw mulching and the restriction of irrigation water on soluble solids, titratable acidity, total sugars and total anthocyanin in the trail field of king ruby grape during 2017 and 2018 seasons.

\begin{tabular}{ccccccccc}
\hline Parameters & \multicolumn{2}{c}{ Soluble solids( ${ }^{\circ}$ Birx $)$} & \multicolumn{2}{c}{$\begin{array}{c}\text { Titratable acidity } \\
\left(\mathbf{g ~ L}^{-1}\right)\end{array}$} & Total sugars $\%$ & $\begin{array}{c}\text { Total } \\
\text { Anthocyanin } \\
\left(\mathbf{m g 1 0 0 g}^{-1}\right)\end{array}$ \\
\hline Treatments & $\mathbf{2 0 1 7}$ & $\mathbf{2 0 1 8}$ & $\mathbf{2 0 1 7}$ & $\mathbf{2 0 1 8}$ & $\mathbf{2 0 1 7}$ & $\mathbf{2 0 1 8}$ & $\mathbf{2 0 1 7}$ & $\mathbf{2 0 1 8}$ \\
\hline T1 & $17.43 \mathrm{a}$ & $17.42 \mathrm{a}$ & $0.55 \mathrm{c}$ & $0.54 \mathrm{c}$ & $13.02 \mathrm{a}$ & $13.01 \mathrm{a}$ & $33.36 \mathrm{a}$ & $33.37 \mathrm{a}$ \\
T2 & $17.44 \mathrm{a}$ & $17.43 \mathrm{a}$ & $0.56 \mathrm{c}$ & $0.57 \mathrm{c}$ & $12.98 \mathrm{a}$ & $12.99 \mathrm{a}$ & $33.32 \mathrm{a}$ & $33.30 \mathrm{a}$ \\
T3 & $17.51 \mathrm{~b}$ & $17.52 \mathrm{~b}$ & $0.47 \mathrm{~b}$ & $0.48 \mathrm{~b}$ & $13.16 \mathrm{~b}$ & $13.14 \mathrm{~b}$ & $35.56 \mathrm{~b}$ & $35.52 \mathrm{~b}$ \\
T4 & $17.45 \mathrm{a}$ & $17.44 \mathrm{a}$ & $0.54 \mathrm{c}$ & $0.53 \mathrm{c}$ & $13.03 \mathrm{a}$ & $13.01 \mathrm{a}$ & $33.42 \mathrm{a}$ & $33.41 \mathrm{a}$ \\
T5 & $17.65 \mathrm{c}$ & $17.64 \mathrm{c}$ & $0.45 \mathrm{a}$ & $0.43 \mathrm{a}$ & $13.25 \mathrm{c}$ & $13.24 \mathrm{c}$ & $37.55 \mathrm{c}$ & $37.52 \mathrm{c}$ \\
$\mathrm{T} 6$ & $17.51 \mathrm{~b}$ & $17.53 \mathrm{~b}$ & $0.47 \mathrm{~b}$ & $0.49 \mathrm{~b}$ & $13.17 \mathrm{~b}$ & $13.15 \mathrm{~b}$ & $35.58 \mathrm{~b}$ & $35.57 \mathrm{~b}$
\end{tabular}

T1 (control), T2 (mulch control), T3 (25\% of restriction irrigation water), T4 (25\% of restriction irrigation water with mulching), T5 ( $50 \%$ of restriction irrigation water), T6 ( $50 \%$ of restriction irrigation water with mulching), Means followed by the same letter are not statistically different by Duncanat 0.05 levels.

results of total chlorophyll content appeared that T6 had similar results to T1 with no significant differences Table 7 The lowest value of total chlorophyll content was found in T5 then T3, T4 and T2, respectively, Table 7 The lowest value of total carbohydrate was found in T1, T2 and T4 treatments without significant differences between them, Table 7 . T5 treatment showed slightly the highest value of it followed by T3 and T6 with similar results between themTable 7. These results are in accordance with that obtained byGinestaret al. (1998) who stated that excess water content inhibit photosynthesis subsequently reduce total chlorophyll content. On the other hand Deluc et al. (2009) found that total carbohydrates were increased in grapes after exposure to water deficit.

\section{Petiole mineral content}

Interestingly vines that exposed to $50 \%$ of restriction or saving irrigation water in the presence of rice straw mulching (T6) achieved similar uptake of $\mathrm{N}, \mathrm{P}, \mathrm{K}, \mathrm{Ca}$ and $\mathrm{Mg}$ to control (T1, full irrigation regime in the absence of mulching), Table 8, T5 treatment showed the lowest value of all nutrients uptake while T2 treatment revealed the highest value followed by $\mathrm{T} 4$ and T3, respectively, Table 8 . These results are in line with findings from (Agnew et al., 2002 and 2005, Ross 2010 and Nguyen et al., 2013) who found that mulching increasing nitrogen and other nutrients in soils due to the inhibition of leaching and evaporation.

TABLE 7. The effect of rice straw mulching and the restriction of irrigation water leaf chlorophyll content and cane carbohydrate content in the trail field of king ruby grape during 2017 and 2018 seasons.

\begin{tabular}{cccccccc}
\hline Parameters & & T1 & T2 & T3 & T4 & T5 & T6 \\
\hline Total chlorophyll & 2017 & $9.89 \mathrm{c}$ & $11.54 \mathrm{e}$ & $9.22 \mathrm{~b}$ & $10.58 \mathrm{~d}$ & $8.85 \mathrm{a}$ & $9.88 \mathrm{c}$ \\
$\quad$ mg g FW $^{-1}$ & 2018 & $9.87 \mathrm{c}$ & $11.24 \mathrm{e}$ & $9.24 \mathrm{~b}$ & $10.85 \mathrm{~d}$ & $8.65 \mathrm{a}$ & $9.86 \mathrm{c}$ \\
& 2017 & $23.04 \mathrm{a}$ & $22.97 \mathrm{a}$ & $23.12 \mathrm{~b}$ & $23.02 \mathrm{a}$ & $23.26 \mathrm{c}$ & $23.14 \mathrm{~b}$ \\
Total carbohydrate \% & 2018 & $23.03 \mathrm{a}$ & $22.98 \mathrm{a}$ & $23.13 \mathrm{~b}$ & $23.01 \mathrm{a}$ & $23.27 \mathrm{c}$ & $23.13 \mathrm{~b}$ \\
\hline
\end{tabular}

T1 (control), T2 (mulch control), T3 (25\% of restriction irrigation water), T4 (25\% of restriction irrigation water with mulching), T5 ( $50 \%$ of restriction irrigation water), T6 (50\% of restriction irrigation water with mulching), Means followed by the same letter are not statistically different by Duncan at 0.05 levels. 
TABLE8.The effect of rice straw mulching and the restriction of irrigation water on the uptake of nitrogen $(N)$, phosphorus (P), potassium (K), calcium (Ca) and magnesium (Mg) in the trail field of king ruby grape during 2017 and 2018 seasons.

\begin{tabular}{|c|c|c|c|c|c|c|c|c|c|c|}
\hline \multirow{2}{*}{$\begin{array}{l}\text { Parameters } \\
\text { Treatments }\end{array}$} & \multicolumn{2}{|c|}{ N \% } & \multicolumn{2}{|c|}{ P \% } & \multicolumn{2}{|c|}{ K \% } & \multicolumn{2}{|c|}{ Са \% } & \multicolumn{2}{|c|}{ Mg \% } \\
\hline & 2017 & 2018 & 2017 & 2018 & 2017 & 2018 & 2017 & 2018 & 2017 & 2018 \\
\hline T1 & $2.61 \mathrm{c}$ & $2.60 \mathrm{c}$ & $0.39 \mathrm{c}$ & $0.38 \mathbf{c}$ & $2.39 \mathrm{c}$ & $2.39 \mathrm{c}$ & $1.31 \mathrm{c}$ & $1.33 \mathrm{c}$ & $0.51 \mathrm{c}$ & $0.52 \mathrm{c}$ \\
\hline $\mathbf{T 2}$ & $2.88 \mathrm{e}$ & $2.89 \mathrm{e}$ & $0.49 \mathrm{e}$ & $0.48 \mathbf{e}$ & $2.51 \mathrm{e}$ & $2.52 \mathrm{e}$ & $1.57 \mathrm{e}$ & $1.58 \mathrm{e}$ & $0.59 \mathrm{e}$ & $0.58 \mathbf{e}$ \\
\hline T3 & $2.43 \mathbf{b}$ & $2.41 \mathbf{b}$ & $0.30 \mathbf{b}$ & $0.32 \mathbf{b}$ & $2.31 \mathbf{b}$ & $2.32 \mathbf{b}$ & $1.23 \mathbf{b}$ & $1.24 \mathbf{b}$ & $0.37 \mathbf{b}$ & $0.38 \mathbf{b}$ \\
\hline T4 & $2.75 d$ & $2.77 \mathrm{~d}$ & $0.42 d$ & $0.41 \mathrm{~d}$ & $2.44 d$ & $2.45 d$ & $1.43 \mathrm{~d}$ & $1.44 d$ & $0.45 d$ & $0.44 d$ \\
\hline T5 & $2.33 \mathbf{a}$ & $2.35 \mathbf{a}$ & $0.29 \mathbf{a}$ & $0.28 \mathbf{a}$ & $2.27 \mathbf{a}$ & $2.28 \mathbf{a}$ & $1.17 \mathbf{a}$ & $1.18 \mathbf{a}$ & $0.31 \mathbf{a}$ & $0.30 \mathbf{a}$ \\
\hline T6 & $2.59 \mathrm{c}$ & $2.58 \mathrm{c}$ & $0.38 \mathrm{c}$ & $0.39 \mathrm{c}$ & $2.38 \mathrm{c}$ & $2.37 \mathrm{c}$ & $1.30 \mathrm{c}$ & $1.31 \mathrm{c}$ & $0.51 \mathrm{c}$ & $0.50 \mathrm{c}$ \\
\hline
\end{tabular}

T1 (control), T2 (mulch control), T3 (25\% of restriction irrigation water), T4 (25\% of restriction irrigation water with mulching), T5 ( $50 \%$ of restriction irrigation water), T6 (50\% of restriction irrigation water with mulching), Means followed by the same letter are not statistically different by Duncan at 0.05 levels.

\section{Conclusion}

Based on these results, it can be conclude that application of rice straw mulching should be targeted to save $50 \%$ of irrigationwater (T6 treatment) after veraison in vineyards cultivated in Delta Nile of Egypt as alternative agriculture practices for keeping balance of growth parameter, yield level and improving quality of King ruby grapes. To reach this goal authors highly recommend growers to fellow irrigation regime with 20 days irrigation intervals from May till end of July using rice straw covering soil surfaces between rows with renewing it every year at the same period.

\section{Acknowledgment}

The authors wish to acknowledge Tanta University, Egypt for introducing all facilities needed for this study. We also thank all kind of help supported by all members of Horticulture Department and all members of Soil and water Department, Faculty of Agriculture, Tanta University.

\section{Funding statement}

Partial funding of this work was provided by the Faculty of Agriculture, Tanta University, Egypt and there was no external funding received for this study.

\section{Conflicts of interest}

The authors declare that there are no conflicts of interest related to the publication of this work.

\section{References}

A.O.A.C. (2000) Official Methods of Analysis $16^{\text {th }}$ ed., A.O.A.C. Benjamin Franklin Station

Agnew, R.H., Mundy, D.C. and Spiers, T.M. (2002) Mulch for sustainable production. Booklet produced for Marlborough District Council, ISBN No. 0-478 06833-6

Agnew, R.H., Mundy, D.C., Spiers, T.M. and Greven, M.M. (2005) Waste stream utilization for sustainable viticulture. Water Sci. Technol., 51, 1-8

Basile, B., Marsal, J., Mata, M., Valiverdu, X., Belivert, J. and Girona, J. (2011) Phenological sensitivity of Cabernet Sauvignon to water stress: Vine physiology and berry composition. Am. J. Enol. Vitic., 62, 452-46 1

Bindon, K.A., Dry, P.R. and Loveys, B.R. (2008) Influence of partial rootzone drying (PRD) on the composition and accumulation of anthocyanins in grape berries (Vitisvinifera L. cv. Cabernet Sauvignon). Aust. J. Grape.Wine Res., 14, 91-103.

Bravdo, B.A., Hepner, Y., Loigner, C., Cohen, S. andTabacman, H. (1985) Effect of irrigation and crop level on growth, yield, and wine quality of Cabernet Sauvignon. Am. J. Enol. Vitic., 36, 132-139.

Carter, M, Sanderson, J. and MacLeod, J. (2004) Influence of compost on the physical properties and organic matter fractions of a fine sandy loam throughout the cycle of a potato rotation. Canadian Journal of Soil Science, 84, 211-218, doi:10.4141/ S03-058. 
Castellarin, S.D., Pfeiffer, A., Sivilotti, P., Degan, M., Peterlunger, E. and Di Gaspero, G. (2007) Transcriptional regulation of anthocyanin biosynthesis in ripening fruit of grapevine under seasonal water deficit. Plant, Cell Env., 30, 1381-1399.

Chan, K. Y., Fahey, D. J., Newell, M., and Barchia, I. (2010) Using Composted Mulch in VineyardsEffects on Grape Yield and Quality. International Journal of Fruit Science, 10 (4), 441-453.

Chapman, H.D. and Pratt, P.F. (1961) Methods of Analysis for Soils, Plants and Waters Div. Agric. Sci. Univ. Calif. USA, pp, 309.

Chaudhry M. R., Aziz A. M. and Sidhu, M. (2004) Mulching impact on moisture conservation-soil properties and plant growth. Pakistan Journal of Water Resources, 8 (2), 1-8.

Cottenie, A., Verloo, M., Kiekens, L., Velgle, G. and amerlynuck, R. (1982) Chemical Analysis of Plant and Soil, 43- 51. Laboratory of Analytical and Agroch. State Univ. of Belgium, Gent.

Davies, W.J., Zhang, J., Yang, J. and Dodd, I.C. (2011) Novel crop science to improve yield and resource use efficiency in water-limited agriculture. J. Agric. Sci., 149, 123-131. doi:10.1017/ S0021859610001115

Deluc, L.G., Quilici, D.R., Decendit, A., Grimplet, J., Wheatley, M.D., Schlauch, K.A., Merillon, J.M., Cushman, J.C. and Cramer, G.R.(2009) Water deficit alters differentially metabolic pathways affecting important flavor and quality traits in grape berries of Cabernet Sauvignon and Chardonnay. BMC Genomics, 10, 212-225

Dry, P.R., Loveys, B.R., McCarthy, M.G. and Stoll, M. (2001) Strategic irrigation management in Australian vineyards. J. Int. Sci. Vigne Vin, 35, 129-139.

Duncan, D. B. (1955) Multiple ranges and multiple F. test. Biometrics, 11, 1-42.

Elmore, C.L., Donaldson, D.R. and Smith, R.J. (1998) Weed management. In:Ingels CA (Ed.) Cover cropping in vineyards. Univ. California, DivAgr. Natural Resources, Publ. 3338, pp. 107-112

Frederikson, L., Skinkis, P.A. and Peachey, E. (2011) Cover crop and floor management affect weed coverage and density in an establishing Oregon vineyard. Horttechnol., 21, 208-216

Ginestar, C., Eastham, J., Gray, S. andHand, P. (1998) Use of Sap-Flow Sensors to Schedule Vineyard Irrigation. II. Effects of Post-Veraison Water Deficits on Composition of Shiraz Grapes. American Journal of Enology and Viticulture, 49, 421-428.
Göblyös, J., Zanathy, G., Donkó, Á.,Varga, T. and Bisztray, G. (2011) Comparison of three soil management methods in the Tokaj wine region. Mitt Klosterneuburg, 61, 187-195

Gregory, P.J. (2004) Agronomic approaches to increasing water use efficiency. In: Bacon MA (ed) Water use efficiency in plant biology. Blackwell Publishing Ltd., Oxford, pp. 142-167

Grossman, R.B. and T.G. Reinsch (2002) Bulk density and linear extensibility. Methods of Soil Analysis, Part 4., In J.H. Dane and G.C. Topp (ed.). SSSA Book Ser. 5. SSSA, Madison, WI.,pp. 201-228.

Hamman, R. A. and Dami, I. E. (2000) Effects of irrigation on wine grape growth and fruit quality. Hort. Technology, 10, 162-168.

Hamza, D. M. (2013) Physical studies on King Ruby Seedless grapevines. Ph.D. Thesis, Fac. Agric., Mansoura Univ. Egypt

Hedge, I.E. and Hofreiter, B.T. (1962) "Carbohydrate

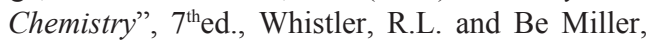
J.N. Academic Press, New York.

Jackson, M.L. (1967) Soil Chemical Analysis.PrinticeHall Inc. Englewood Cliffs-N.S.

Jones, R., Hiederer, R., Rusco, E., Lovel, P. and Montanarella, L. (2003) Topsoil Organic Carbon in Europe. Proceedings of the 4th European Congress on Regional Geoscientific Cartography and Information Systems, Bologna, 17-20.06.2003, p.249- 251.

Kennedy, J.A., Matthews, M.A. and Waterhouse, A.L. (2002) Effect of maturity and vine water status on grape skin and wine flavonoids. Am. J. Enol. Vitic., $\mathbf{5 3}, 268-274$.

Klute, A. (1986) Methods of Soil Analysis, Part 1,2 $2^{\text {nd }}$ ed. Agron. Monogr. Q.ASA, Madison, WI.

Kostiakov, A.N. (1932) On the Dynamics of the Confinement of Water Percolation in Soils and on the Necessity of Studying it from a Dynamic Point of View for Purpose of Amelioration.Society of soil science, Russia, 14, 17-21.

Laila, K. and Ali, M. (2011) A study of some methods of waste management of rice through its impact on soil physical properties, N, P and $\mathrm{K}$ contents in maize yield and water use efficiency under different tillage systems. Australian Journal of Basic and Applied Sciences, 5 (5), 1017-1034.

Matthews, M.A. and Anderson, M.M.(1989) Reproductive development in grape (Vitisvinifera L.): Responses to seasonal water deficits. Am. J. Enol. Vitic., 40, 52-60. 
McCarthy, M.G., Loveys, B.R., Dry, P.R. and Stoll, M. (2002) Regulated deficit irrigation and partial rootzone drying as irrigation management techniques for grapevines.FAO Water Reports, 22, 79-87.

Némethy, L. (2004) Alternative soil management for sandy vineyards. ActaHortic., 640, 119-125.

Nguyen, T., Fuentes, S. and Marschener, P. (2013) Effect of incorporated or mulched compost on leaf nutrient concentrations and performance for Vitisviniferacv. Merlot.J. Soil Sci. Plant Nutr., 13, 485-497. doi:10.4067/S0718-95162013005000038

Omran, Y.A.M. (2000) Studies on histophysiological effect of dormex and yeast application on bud fertility, vegetative growth and yield of Romy red grapevines. Ph.D. Thesis, Fac. Agric., AssuitUniv.

Page, A. L. (1982) Method of Soil Analysis, Part 2, Chemical and Microbiological Properties, $2^{\text {nd }}$ ed., American Society of Agronomy, Inc and Soil Science Society of America, Inc., Publisher, Madison, Wisconsin USA.

Pellegrino, A.,Clingeleffer, P.,Cooley, N. andWalker, R. (2014) Management practices impact vine carbohydrate status to a greater extent than vine productivity. Frontiers in Plant Science, 5,283 doi:10.3389/fpls.2014.00283.

Reynolds, W., Bowman, B., Brunke, R., Drury, C. and Tan C. (2000) Comparison of tensioninfiltrometer, pressure infiltrometer and soil core estimates of saturated hydraulic conductivity. Soil Science Society of America journal, 64 (2),doi:10.2136/ sssaj2000.642478x.

Roby, G., Harbertson, J.F., Adams, D.A. and Matthews, M.A.(2004) Berry size and vine water deficits as factors in winegrape composition: Anthocyanins and tannins. Aust. J. Grape Wine Res., 10, 100-107.

Ross, O.C. (2010) Reflective mulch effects on the grapevine environment,Pinot noir vine performance, and juice and wine characteristics. Dissertation, Lincoln University

Santos, T.P., Lopes, C.M., Rodrigues, M.L., Souza, C.R., Ricardo-da-Silva, J.M., Maroco, J.P., Pereira, J.S. and Chaves, M.M.(2007) Effect of deficit irrigation strategies on cluster microclimate for improving fruit composition of Moscatel fieldgrown grapevines. Sci. Hort., 112, 321-330.
Smart, R.E. (1985)Principles of grapevine canopy microclimate manipulation with implications for yield and quality. A review.American Journal of Enology and Viticulture, 36, 230-239.

Steinmaus, S., Elmore, C.L., Smith, R.J., Donaldson, D.,Weber, E.A., Roncoroni, J.A. and Miller, P.R.M. (2008) Mulched cover crops as an alternative to conventional weed management systems in vineyards. Weed Res (48), 273-28. doi:10.1111/ j.1365-3180.2008.00626.x

Valdés, E., Moreno, D., Gamero, E., Uriarte, D., Prieto, M.H., Manzano, R., Picón, J. and Intrigliolo, D.(2009) Effects of cluster thinning and irrigation amount on water relations, growth, yield and fruit and wine composition of Tempranillo grapes in Extremadura (Spain). J. Int. Sci. VigneVin., 43, 6776

Von-Wettstein, D.V.C. (1957) Clatale und der Sumbmikro Skopisne Formwechsel de Plastids. Experimental Cell Research, $12-427$

Wheeler JM, Taylor BH, Young BG. (2008)Grapevine response to ground cover management in a humid climate. In: Abstracts from Presentations at the ASEV Eastern Section 32nd Annual Meeting 15-17 July 2007, Lehigh Valley, Pennsylvania. American Journal of Enology and Viticulture,59, 111A.

Wilde, A.A., Corey, R.B.,Lyer , J.G. andVoigt, G.K. (1985)Soil and Plant Analysis For Tree Culture. $3^{\text {rd }}$ ed., Oxford IBH Publishing Co., New Delhi, pp.: 64-115.

Williams, L.E. and Matthews, M.A. (1990) Grapevine. In: Stewart BA, Nielson DR, (Ed.), Irrigation of agricultural crops. Madison: American Society of Agronomy, 1019-1048.

Zhang, G.,Wang, S., Li, L., Inoue, M., Xiang, J., Qiu, G. and Jin,W. (2014) Effects of mulching and sub-surface irrigation on vine growth, berry sugar content and water use of rapevines. Agric. Water Manag., 143,1-8. doi:10.1016/j.agwat.2014.05.015

Zhang, X., Chen, S., Liu, M., Pei, D., Sun, H. ( 2005) Improved water use efficiency associated with cultivars and agronomic management in the North China. Plain. Agron. J., 97, 783-790.

(Received 22/12/2018; accepted 13/01/2019) 


\section{تأثثير التغطية بقش الأرز على كفاءة إستخدام المياه ونمو ومحصول وجودة عنب الكنج روبى تحت ظروف الزّى السطى}

"عاطف مصطفى أبو عجيلة و**تجلاء إبرا هيم خلف الله

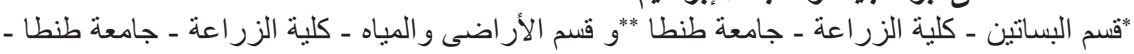
طنطا - مصر التئر

مايو حتى نهاية شهر يوليو (وقت الحصاد) وذلك بتصميم تجربة قطاعات كاملة العشو ائية بست معاملات تم

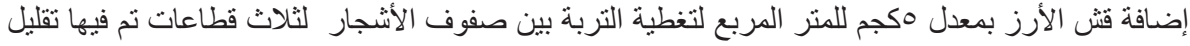

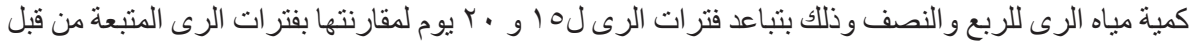

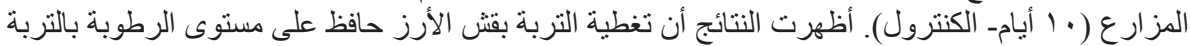

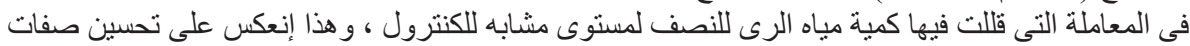

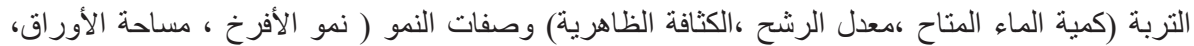

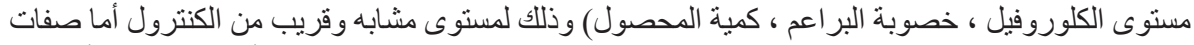

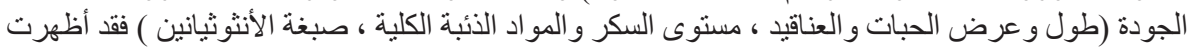

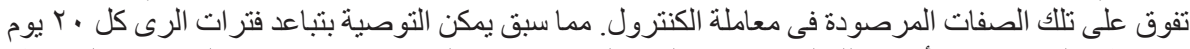

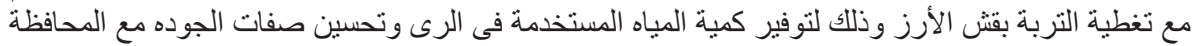
على كمية المحصول فى المستوى الأمثل.

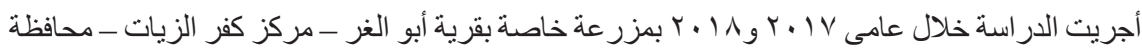

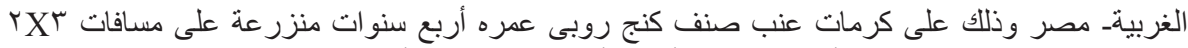

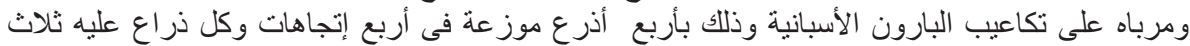

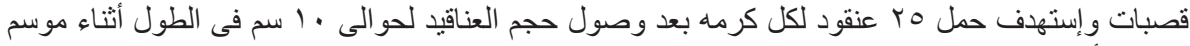

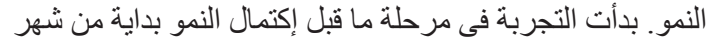

